Bull. Chem. Soc. Ethiop. 2016, 30(3), 421-425.

Printed in Ethiopia

DOI: http://dx.doi.org/10.4314/bcse.v30i3.10

ISSN 1011-3924

(c) 2016 Chemical Society of Ethiopia

\title{
SYNTHESIS AND ANTIBACTERIAL EVALUATION OF SOME NOVEL MANNICH BASES OF BENZIMIDAZOLE DERIVATIVES
}

\author{
A. Ahmadi* \\ Department of Chemistry, Faculty of Science, Karaj Branch, Islamic Azad University, Karaj, \\ Iran
}

(Received January 29, 2016; revised May 19, 2016)

\begin{abstract}
Substituted benzimidazoles are known for their chemotherapeutic importance and many pharmacological properties. In this paper, we synthesized some novel Mannich bases of benzimidazole derivatives. The synthesized compounds were characterized by their physical and spectral data and in vitro antibacterial activity of these compounds tested against Bacillus subtilis, Bacillus pumilus, Escherichia coli and Pseudomonas aeruginosa organisms. The potency of the synthesized compounds was determined against standard drug Ciprofloxacin by measuring the zone of inhibition.
\end{abstract}

KEY WORDS: Benzimidazole, Mannich base, Antimicrobial activity

\section{INTRODUCTION}

Infectious microbial diseases remain pressing problems worldwide, because resistance to a number of antimicrobial agents among variety of clinically significant species of microorganisms has become an important global health problem. One way to battle with this challenge is the conscious usage of the currently marketed antibiotics; the other is the development of novel antimicrobial agents [1-8]. Hence, there will always be a vital need to discover new chemotherapeutic agents to avert the emergence of resistance and ideally shorten the duration of therapy. Benzimidazole nucleus is an important heterocyclic ring. Substituted benzimidazole have received considerable attention during last decades as they are endowed with variety of biological activities and have wide range of therapeutic properties. A literature survey indicates that benzimidazole derivatives possess different pharmacological and biological properties like antibacterial, anti-inflammatory, antifungal, anti-tubercular, anticancer, anthelmintic activity, etc. Combination of two or more active moieties into one is a common procedure of manipulation and this can possibly results in augmenting the activity, removal of untoward side effects and particularly prevent the development of resistance by the infectious micro-organisms [9-14].

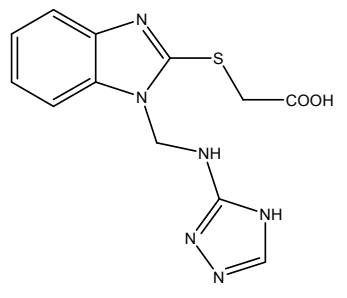

III

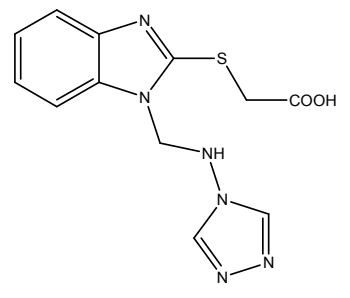

VI

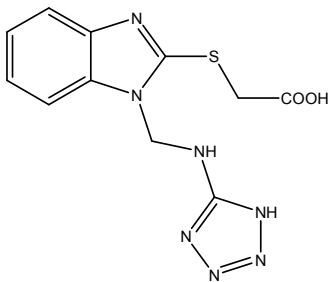

V

*Corresponding author. E-mail: a-ahmadi@kiau.ac.ir; ahmadikiau@yahoo.com 
Figure 1. The target compounds for synthesizing.

By considering the above facts, we plan to synthesize a bi heterocyclic system comprising of benzimidazole nucleus and biologically important heterocyclic systems like triazoles and tetrazoles system (Figure 1). We have also planned to evaluate the synthesized compounds for anti-bacterial activity.

\section{EXPERIMENTAL}

\section{Material and equipments}

All of chemicals and solvents were purchased from Merck (Darmstadt, Germany) and SigmaAldrich chemical Co. (USA). Melting points (uncorrected) were determined with a digital Electrothermal melting point apparatus (model 9100, Electrothermal Engineering Ltd., Essex, UK). ${ }^{1} \mathrm{H}$ and ${ }^{13} \mathrm{C}$-NMR spectra were recorded with a Bruker $300 \mathrm{MHz}$ (model AMX, Karlsruhe, Germany) spectrometer (internal reference: TMS). IR spectra were recorded with a Thermo Nicolet FT-IR (model Nexus-870, Nicolet Instrument Corp, Madison, Wisconsin, USA) spectrometer. Mass spectra were recorded with an Agilent Technologies 5973, Mass Selective Detector (MSD) spectrometer (Wilmington, USA).

\section{Preparations (Scheme 1)}

2-Mercapto benzimidazole (I). A mixture of $o$-phenylenediamine $(0.1 \mathrm{~mol})$, potassium hydroxide $(0.1 \mathrm{~mol})$, and carbon disulfide $(0.1 \mathrm{~mol}), 100 \mathrm{~mL}$ of $95 \%$ ethanol and $15 \mathrm{~mL}$ of water were refluxed for $3 \mathrm{~h}$. Then warm water was added and acidified with dilute acetic acid. The product was filtered and dried and is recrystalized by ethanol [15]. White needle crystals; yield $73 \%$; m.p. $300-302{ }^{\circ} \mathrm{C}$.

(1H-benzimidazol-2-ylthio) acetic acid (II). A mixture containing 2-mercaptobenzimidazole $(0.013 \mathrm{~mol}), 20 \mathrm{~mL}$ of ethanol, potassium hydroxide $(0.016 \mathrm{~mol})$ was refluxed for $1 \mathrm{~h}$. After cooling the resulting solution to $30{ }^{\circ} \mathrm{C}$ added chloroacetic acid $(0.012 \mathrm{~mol})$. After stirring at 25 $30{ }^{\circ} \mathrm{C}$ for $18 \mathrm{~h}$, the reaction mixture was added to $100 \mathrm{~g}$ of ice-water and stirred for $30 \mathrm{~min}$ at 0 $10{ }^{\circ} \mathrm{C}$. The obtained precipitate was collected by filtration, washed with water until free of chloride, air dried at $50{ }^{\circ} \mathrm{C}$ and recrystalized from water [16-18]. White needle crystals; yield $75 \%$; m.p. $214-216{ }^{\circ} \mathrm{C}$. IR (KBr) $\left(\mathrm{cm}^{-1}\right): 3153(\mathrm{OH}), 3114(\mathrm{NH}), 2980,2917(\mathrm{Ar}-\mathrm{CH}=\mathrm{CH})$, and $1675(\mathrm{C}=\mathrm{O}$ absorption band of $\mathrm{COOH}) . \mathrm{H}-\mathrm{NMR}(\delta, \mathrm{ppm}): 12.7(1 \mathrm{H}, \mathrm{bs}, 1 \mathrm{H}$ of benzimidazole $\mathrm{NH}), 12.5(1 \mathrm{H}, \mathrm{s}, 1 \mathrm{H}$ of $\mathrm{OH}$ of $\mathrm{COOH}), 7.0-7.43(4 \mathrm{H}, \mathrm{m}, 4 \mathrm{H}$ of $\mathrm{Ar}-\mathrm{H}), 4.12\left(2 \mathrm{H}, \mathrm{s}, 2 \mathrm{H}\right.$ of $\mathrm{CH}_{2}$ of $\mathrm{CH}_{2} \mathrm{COOH}$ ). $\mathrm{C}_{9} \mathrm{H}_{8} \mathrm{~N}_{2} \mathrm{O}_{2}$ S. MS: m/z (regulatory intensity): 208 (100), 209 (8), 210 (4).

General procedure for the synthesis of Mannich Bases (III-V). Benzimidazolylthioacetic acid (II) $(0.002 \mathrm{~mol})$ dissolved in ethanol and 3-4 drops of conc. $\mathrm{HCl}$ was added and reaction mixture was kept for stirring. To the stirring reaction mixture, formaldehyde $(0.002 \mathrm{~mol})$ was added drop wise and stirring was continued for $10 \mathrm{~min}$. Meanwhile $0.002 \mathrm{~mol}$ appropriate amine $\left(\mathrm{R}-\mathrm{NH}_{2}\right)$ was dissolved in ethanol and was added into the above reaction mixture drop wise with continuous stirring. After stirring the reaction, mixture was refluxed for $12 \mathrm{~h}$. The mixture was allowed to cool at room temperature. The solid thus separated was filtered and dried. The obtained products (III-V) were re-crystallized from ethanol [19, 23].

$\{1-[(4 H-[1,2,4]$ Triazol-3-ylamino)-methyl]-1H-benzimidazol-2-ylsulfanyl\}-acetic acid (III). White needle crystals; yield $65 \%$; m.p. $254-256{ }^{\circ} \mathrm{C}$. IR $(\mathrm{KBr})\left(\mathrm{cm}^{-1}\right): 3180(\mathrm{NH}), 2950,2870$ $(\mathrm{Ar}-\mathrm{CH}=\mathrm{CH})$, and $1678(\mathrm{C}=\mathrm{O}$ absorption band of $\mathrm{COOH}) . \mathrm{H}-\mathrm{NMR}(\delta, \mathrm{ppm}): 9.6(1 \mathrm{H}, \mathrm{s}, 1 \mathrm{H}$ of $\mathrm{OH}$ of $\mathrm{COOH}), 7.6(1 \mathrm{H}, \mathrm{s}, 1 \mathrm{H}$ of $\mathrm{NH}$ of triazole $), 6.4-7.3(6 \mathrm{H}, \mathrm{m}, 4 \mathrm{H}$ of $\mathrm{Ar}-\mathrm{H}, 1 \mathrm{H}$ of $\mathrm{CH}$ of triazole, $1 \mathrm{H}$ of $\mathrm{NH}), 4.8\left(2 \mathrm{H}, \mathrm{d}, 2 \mathrm{H}\right.$ of $\left.\mathrm{N}^{-C_{2}}-\mathrm{NH}-\right), 3.9-4\left(2 \mathrm{H}, \mathrm{d}, 2 \mathrm{H}\right.$ of $\left.\mathrm{CH}_{2} \mathrm{COOH}\right)$. Anal. 
calcd. for $\mathrm{C}_{12} \mathrm{H}_{12} \mathrm{~N}_{6} \mathrm{O}_{2} \mathrm{~S} ; \mathrm{C}, 47.36 ; \mathrm{H}, 3.97 ; \mathrm{N}, 27.62 \%$. Found: C, 47.19; H, 3.79; N, 27.54\%. MS: $\mathrm{m} / \mathrm{z}$ (regulatory intensity): 304 (100), 305 (13.6), 306 (5).

[1-([1,2,4]Triazol-4-ylaminomethyl)-1H-benzimidazol-2-ylsulfanyl]-acetic acid (IV). White needle crystals; yield 55\%; m.p. 224-226 ${ }^{\circ} \mathrm{C}$. IR $(\mathrm{KBr})\left(\mathrm{cm}^{-1}\right): 3200(\mathrm{NH}), 2943,2861$ (Ar$\mathrm{CH}=\mathrm{CH})$, and $1652(\mathrm{C}=\mathrm{O}$ absorption band of $\mathrm{COOH}) . \mathrm{H}-\mathrm{NMR}(\delta, \mathrm{ppm}): 10.16(1 \mathrm{H}, \mathrm{s}, 1 \mathrm{H}$ of $\mathrm{OH}$ of $\mathrm{COOH}), 6.4-8.3(6 \mathrm{H}, \mathrm{m}, 4 \mathrm{H}$ of $\mathrm{Ar}-\mathrm{H}, 2 \mathrm{H}$ of $\mathrm{CH}$ of triazole $), 5.1\left(2 \mathrm{H}, \mathrm{d}, 2 \mathrm{H}\right.$ of $\mathrm{N}_{-} \mathrm{CH}_{2}-$ $\mathrm{NH}-), 3.8-4.1\left(2 \mathrm{H}, \mathrm{d}, 2 \mathrm{H}\right.$ of $\left.\mathrm{CH}_{2} \mathrm{COOH}\right)$. Anal. calcd. for $\mathrm{C}_{12} \mathrm{H}_{12} \mathrm{~N}_{6} \mathrm{O}_{2} \mathrm{~S} ; \mathrm{C}, 47.36 ; \mathrm{H}, 3.97$; , $27.62 \%$. Found: C, 47.33; H, 3.71; N, 27.63\%. MS: m/z (regulatory intensity): 304 (100), 305 (13.5), $306(5)$.

\{1-[(1H-Tetrazol-5-ylamino)-methyl]-1H-benzimidazol-2-ylsulfanyl\}-acetic acid (V). White needle crystals; yield 50\%; m.p. 234-236 ${ }^{\circ} \mathrm{C}$. IR $(\mathrm{KBr})\left(\mathrm{cm}^{-1}\right): 3340(\mathrm{NH}), 2932,2856$ (Ar$\mathrm{CH}=\mathrm{CH})$, and $1702(\mathrm{C}=\mathrm{O}$ absorption band of $\mathrm{COOH}) . \mathrm{H}-\mathrm{NMR}(\delta, \mathrm{ppm}): 10.76(1 \mathrm{H}, \mathrm{s}, 1 \mathrm{H}$ of $\mathrm{OH}$ of $\mathrm{COOH}), 7.4-7.9(4 \mathrm{H}, \mathrm{m}, 4 \mathrm{H}$ of $\mathrm{Ar}-\mathrm{H}), 5.4\left(2 \mathrm{H}, \mathrm{d}, 2 \mathrm{H}\right.$ of $\left.\mathrm{N}-\mathrm{CH}_{2}-\mathrm{NH}-\right), 3.87-4.15(2 \mathrm{H}, \mathrm{d}$, $2 \mathrm{H}$ of $\mathrm{CH}_{2} \mathrm{COOH}$ ). Anal. calcd. for $\mathrm{C}_{11} \mathrm{H}_{11} \mathrm{~N}_{7} \mathrm{O}_{2} \mathrm{~S} ; \mathrm{C}, 43.27 ; \mathrm{H}, 3.63 ; \mathrm{N}, 32.11 \%$. Found: $\mathrm{C}$, 43.33; H, 3.71; N, 32.23\%. MS: m/z (regulatory intensity): 305 (100), 306 (15), 307 (6).<smiles>Nc1ccccc1N</smiles>

o-phenylene diamine

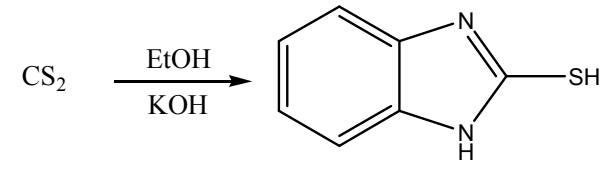

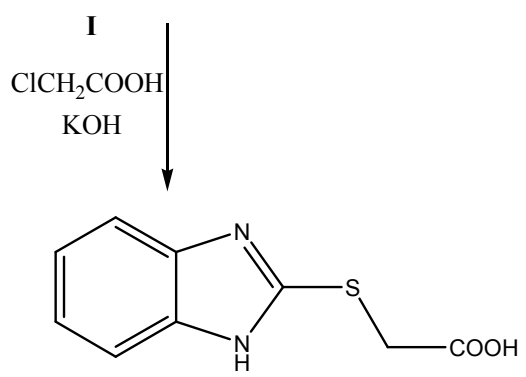

II

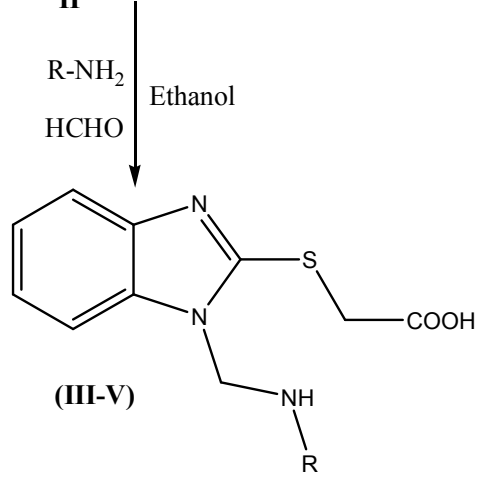

Scheme 1. Scheme of synthesis for intermediates (I and II) and final compounds (III-V). 
Antimicrobial activity

Antibacterial activity was carried out by disc diffusion method using Bacillus subtilis, Bacillus pumilus, Escherichia coli and Pseudomonas aeruginosa organisms for antibacterial activity. The potency of the synthesized compounds was determined against standard drug Ciprofloxacin by measuring the zone of inhibition [24-26].

\section{RESULTS AND DISCUSSION}

The starting compound 2-mercapto benzimidazole (I) was prepared from $o$-phenylene diamine, potassium hydroxide and carbon disulfide upon refluxing for $3 \mathrm{~h}$ in single step, respectively. The I was refluxed for $60 \mathrm{~min}$ with potassium hydroxide, followed by chloroacetic acid and stirred for $18 \mathrm{~h}$ to furnish (1H-benzimidazol-2-ylthio) acetic acid (II). The different Mannich bases (III-V) were synthesized by refluxing the appropriate substituted amines, formaldehyde with II in ethanolic medium for $12 \mathrm{~h}$. The synthesized compounds were characterized by their physical and spectral data.

The resulted synthesized compounds (III-V) were screened for antibacterial activity studies at a concentration of $100 \mu \mathrm{g} / \mathrm{mL}$ using DMF as a control against Bacillus subtilis, Bacillus pumilus, Escherichia coli and Pseudomonas aeruginosa by disc diffusion method on agar nutrient media. Ciprofloxacin was used as standard drug for the comparison at the concentration of $100 \mu \mathrm{g} / \mathrm{mL}$ against Gram (+ve) and Gram (-ve) bacteria used for the study.

The data in the Table 1 indicates that the compounds were found to possess moderate to weak activity although several benzimidazoles were reported for good antibacterial activity. The compound III was active against Pseudomonas aeruginosa, and the compounds III, IV and V were active against Bacillus subtilis, whereas the compounds IV and $\mathbf{V}$ were active against Bacillus pumilus, rest of the compounds showed only weak activity when compared to the standard ciprofloxacin [26].

Table 1. Anti-bacterial activity of synthesized compounds (III-VI).

\begin{tabular}{|c|c|c|c|c|}
\hline \multirow{2}{*}{ Entry } & \multicolumn{4}{|c|}{ *Inhibition of zone diameter in mm } \\
\cline { 2 - 5 } & B. subtilis & B. pumilus & E. coli & P. aeruginosa \\
\cline { 2 - 5 } & $100 \mu \mathrm{g} / \mathrm{mL}$ & $100 \mu \mathrm{g} / \mathrm{mL}$ & $100 \mu \mathrm{g} / \mathrm{mL}$ & $100 \mu \mathrm{g} / \mathrm{mL}$ \\
\hline III & 17 & 12 & 8 & 16 \\
\hline IV & 19 & 17 & 12 & 10 \\
\hline V & 18 & 19 & 11 & 14 \\
\hline Ciprofloxacin & 28 & 30 & 32 & 30 \\
\hline DMF & - & - & - & - \\
\hline
\end{tabular}

\section{CONCLUSIONS}

A series of some novel benzimidazoles were synthesized and evaluated for their potential antimicrobial activities. Based on results, it can be concluded that all the synthesized compounds showed good to moderate antimicrobial activities. The results indicated that new antimicrobial compounds could be prepared by changing of different substrates on various benzimidazole derivatives. These new compounds could be evaluated for further pharmacological activities in other studies. 


\section{ACKNOWLEDGEMENTS}

The author gratefully acknowledges financial support of Islamic Azad University for this research project.

\section{REFERENCES}

1. Ozkay, Y.; Tunali, Y.; Karaca, H.; Srikdag, I. Eur. J. Med. Chem. 2010, 45, 3293.

2. Varala, R.; Enugala, R. Chem. Pharm. Bull. 2007, 55, 1254.

3. Dubey, R.; Moorthy N.S.H.N. Chem. Pharm. Bull. 2007, 55, 115.

4. Utku, S.; Gokce, M.; Ozcelik, B.; Bercin, E. Turk. J. Pharm. Sci. 2008, 5, 107.

5. Nakano, H.; Inoue, T.; Kawasaki, N.; Miyataka, H.; Matsumoto, H.; Taguchi, T.; Inagaki, N.; Nagai, H.; Satoh, T. Chem. Pharm. Bull. 1999, 47, 1573.

6. Habernickel, V.J. Drugs Made in Germany 1992, 35, 97.

7. Islam, I.; Skibo, E.B.; Dorr, R.T.; Alberts, D.S. J. Med. Chem. 1991, 34, 2954.

8. Kruse, L.L.; Ladd, D.L.; Harrsch, R.B.; McCabe, F.L.; Mong, S.M.; Faucette, L. J. Med. Chem. 1989, 32, 409.

9. Fukuda, T.; Morimoto, Y.; Iemura, R.; Kawashima, T.; Tsukamoto, G.; Ito, K. Drug Res. 1984, 34, 801.

10. Ayhan-Kilcigil, G.; Kus, C.; Çoban, T.; Can-Eke, B. J. Enz. Inhib. Med. Chem. 2004, 19, 129.

11. Kus, C.; Ayhan-Kilcigil, G.; Can-Eke, B.; Iscan, M. Arch. Pharm. Res. 2004, 27, 156.

12. Can-Eke, B.; Puskullu, M.O.; Buyukbingol, E.; Iscan, M. Chemico-Biolog Interact. 1998, $113,65$.

13. Göker, H.; Kilcigil, G.A.; Tuncbilek, M. Heterocycles 1999, 51, 2561.

14. Göker, H.; Kus, C.; Boykin, D.W.; Yildiz, S.; Altanlar, N. Biorg. Med. Chem. 2002, 10, 2589.

15. Ahmadi, A. Bull. Chem. Soc. Ethiop. 2014, 28, 451.

16. Habib, N.S.; Abdel-Hamid, S.; El-Hawash, M. Farmaco 1989, 44, 1225.

17. Coburn, R.A.; Clark, M.T.; Evans, R.T.; Genco, R.J. J. Med. Chem. 1987, 30, 205.

18. Soliman, F.S.G.; Rida, S.M.; Badawey, E.A.M.; Kappe, T. Arch. Pharm. 1984, 317, 951.

19. Abdel-Rahman, A.E.; Mahmoud, A.M.; El-Naggar, G.M.; El-Sherief, H.A. Pharmazie 1983, $38,589$.

20. Finar, I.L. Organic Chemistry: Stereochemistry and the Chemistry of Natural Products, Vol. 2, 5th ed., John Wiley and Sons: New York; 1975; p 631.

21. Furniss, B.S.; Hannaford, A.J.; Smith, P.W.G.; Tatchell, A.R. Vogel Textbook of Practical Organic Chemistry, Vol. 5, Longman-ELBS: London; 2007; pp 1162-1163.

22. Mundy, B.P. Thionyl Bromide in Encyclopedia of Reagents for Organic Synthesis, Paquette, E. (Ed.), John Wiley and Sons: New York; 2004.

23. Advait, S.N.; Ralph, N.S.; Byong-Don, Ch.; Kyung, W.J. Tetrahedron Lett. 2000, 41, 3011.

24. Pharmacopoeia of India, Govt. of India, Ministry of Health and Family Welfare, New Delhi, Vol II, 1996, A-111.

25. Srivastava, S.K.; Verma, S.; Srivastava, S.D. J. Chem. Pharm. Res. 2010, $2,270$.

26. Garkani-Nejad, Z.; Saneie, F. Bull. Chem. Soc. Ethiop. 2010, 24, 317. 